\title{
Air Pollution Characteristics of Reclamation of Refuse Derived Fuel (RDF) Recovered from Cutting Oil Waste
}

\author{
Yi-Ming Kuo ${ }^{1 *}$, Yu-Kuan Wang ${ }^{2}$, Sheng-Lun Lin ${ }^{3}$, Li-Te Yin ${ }^{4}$, Yen-Kung Hsieh ${ }^{5 * *}$ \\ ${ }^{1}$ Department of Safety Health and Environmental Engineering and Department of Optometry, Chung Hwa University of \\ Medical Technology, Tainan 71703, Taiwan \\ ${ }^{2}$ She Ching Enterprise Co., Ltd., Tainan 74443, Taiwan \\ ${ }^{3}$ Department of Civil Engineering and Geomatics, Super Micro Mass Research and Technology Center, and Center for \\ General Education, Cheng Shiu University, Kaohsiung 83347, Taiwan \\ ${ }^{4}$ Department of Optometry, Chung Hwa University of Medical Technology, Tainan 71703, Taiwan \\ ${ }^{5}$ Ocean Affairs Council, Kaohsiung 80661, Taiwan
}

\begin{abstract}
The object of this study is to investigate the emission characteristics of reclamation of refuse-derived fuel (RDF) to evaluate the feasibility of substitution of RDF for current fuels. The cutting oil collected from a canned-food factory was pretreated, mixed with wood dust and bentonite, and was remolded into pellet RDF. Input materials, including coal, wood dust, and remolded RDF, were reclaimed in a steam generation plant. The pollutant characteristics of bottom ash, fly ash, and flue gas were analyzed to evaluate the combustion performance of the tested fuels. The PCDD/F concentration of the flue gas in the runs without coal (19.6 and $21.9 \mathrm{ng}$ I-TEQ $\mathrm{Nm}^{-3}$ ) was two orders higher than those in the runs with coal (0.226 and $0.017 \mathrm{ng}$ I-TEQ $\mathrm{Nm}^{-3}$ ) due to partial smoldering. Except for coal, the substitution of RDF for wood dust also reduced the formation of $\mathrm{PCDD} / \mathrm{Fs}$. According to the monitoring data for $\mathrm{CO}, \mathrm{O}_{2}$, and combustion efficiency, RDF further improved the combustion condition with the aid of coal. The results show that reclamation of RDF is a promising method to take both waste treatment and energy regeneration into consideration.
\end{abstract}

Keywords: Combustion efficiency; Ash; RDF; Wood dust; Coal.

\section{INTRODUCTION}

Due to the current economic growth, the amount of waste generated has increased rapidly during the last several decades. The treatment of waste has thus become a worldwide issue. Therefore, a European strategy for waste management imposed a regulation on the following waste hierarchy to apply as a priority in waste management and treatment: prevention, reuse, recycling, recovery of energy or resources, and disposal (Directive 2008/98/EC). Among the management and treatment strategies, the recovery of energy from waste has been investigated for the last few decades (Chang et al., 1999). There are three available processes, including combustion, gasification, and pyrolysis, to convert biowaste into energy.

\footnotetext{
* Corresponding author.

Tel.: +886-6-2674567 ext. 854; Fax: +886-6-2675049

E-mail address: kuoyiming@gmail.com

** Corresponding author.

Tel.: +886-7-3381810 ext. 854; Fax: +886-7-3380732

E-mail address: yk886963@gmail.com
}

Among them, the combustion process, generally called incineration, is the most commonly used treatment technology for solid waste (Lombardi et al., 2015).

The incineration process converts waste into different forms of energy, such as electricity, steam, and process heat for the utilization of industrial facilities (Murer et al., 2011; Vermeulen et al., 2011). Incineration allows efficient treatment of different types of waste, including municipal solid waste, organic sludge, refuse-derived fuels (RDFs), and even unsorted residual waste (Arena, 2012; Myrin et al., 2014; Leme et al., 2014). In addition, incineration at a high temperature is an efficient technology by which to convert waste into energy and has several advantages.

First, incineration greatly reduces the mass (about $70-80 \%$ ) and the volume (about $80-90 \%$ ) of the waste and preserves landfill space (Consonni et al., 2005). It can destroy organic contaminants (Buekens and Cen, 2011) and reduce greenhouse gas emissions in comparison with anaerobic decomposition (Psomopoulos et al., 2009). According to life cycle assessment studies, it alleviates environmental burdens due to the generation of energy from various kinds of wastes (Arena et al., 2003; Azapagic et al., 2004).

From a sustainable development perspective, the production 
of refuse-derived fuel (RDF) is a promising waste-to-energy technology which has been utilized in the past few decades to solve both waste and energy problems simultaneously (Rada and Andreottola, 2012). Processed waste with high calorie was segregated, mixed, and remolded into RDF (Nasrullah et al., 2015). The reclamation of RDF using thermal processes has received worldwide attention due to its effective recovery of energy from the solid waste (Zhou et al., 2013; Gug et al., 2015). However, persistent organic pollutants are inevitably generated because the RDF is reclaimed using a thermal process (Myrin et al., 2014; Nam-Chol and Kim, 2017). Therefore, the pollutant characteristics of RDF during incineration deserve more detailed investigation.

In the can manufacturing process, cutting oil is used to lubricate cutting tools and dissipate the heat. After operation for a period of time, the quality of the cutting oil deteriorates and must be renewed. The spent cutting oil waste has water, heavy metals and impurities and, thus, requires further disposal. The main component in cutting oil is palm oil, due to its high heating value and the fact that it is suitable to recover as a fuel. Water, heavy metals, and impurities must be removed before remolding spent cutting oil waste into RDF to avoid secondary pollution. However, palm oil is in the form of an ointment at room temperature and has to be heated for the purpose of being melted before the separation process.

In this study, spent cutting oil waste collecting from a canned-food factory was pretreated, mixed with wood dust, and remolded into RDF. The pollutant characteristics during the reclamation of RDF in a steam generation plant were investigated. The pollutant characteristics of the flue gas, fly ash, and bottom ash were evaluated under various combustion conditions to assess the RDF reclamation performance.

\section{METHODS}

\section{Preparation of RDF and Input-materials of Tests}

The spent cutting oil waste was collected from a cannedfood factory located in Southern Taiwan. The oil waste under consideration was stored in 55-gallon oil drums and transported to Shi-Chang Co., ltd. for further treatment. Fig. 1 shows a flow chart of the RDF manufacturing process. Because it is in a solid form at room temperature, the spent cutting oil waste had to be heated to above $70^{\circ} \mathrm{C}$ and melted to reduce its viscosity. The fluidized oil waste was spun at a rotation speed of $11,000 \mathrm{rpm}$ using a centrifugation unit to remove its water content, heavy metals, and impurities. Before being cooled down, the treated oil waste was mixed with wood dust and bentonite. The wood dust served as an additive to adjust the heat value and increase the physical strength of the RDF. Bentonite is an absorbent aluminium phyllosilicate clay consisting mostly of montmorillonite that serves as a binder for ointment and wood dust. The ingredients of the RDF in this study included treated ointment $(65.5 \mathrm{wt} \%)$, wood dust $(34 \mathrm{wt} \%)$, and bentonite $(0.5 \mathrm{wt} \%)$. The mixed materials were compressed at a pressure of $20 \mathrm{~kg} \mathrm{~cm}^{-2}$ to form pellet RDF with a diameter of approximately $5 \mathrm{~cm}$.

There were three fuels, coal, RDF, and wood dust, used in the combustion tests for which the properties are shown in Table 1. The coal, classified as sub-bituminous coal, comprised $78.5 \%$ combustibles and was mainly composed of $\mathrm{C}(77.3 \%)$. It provides $5,230 \mathrm{kcal} \mathrm{kg}^{-1}$ of energy, $16.3 \%$ of which is bottom ash during the combustion process. In the case of the wood dust, the ternary components were moisture (11.1\%), combustibles $(88.4 \%)$, and ash $(0.5 \%)$. The element composition of the combustibles included $\mathrm{C}(58.6 \%)$, $\mathrm{O}(20.6 \%)$, and $\mathrm{H}(7.28 \%)$, with a trace of $\mathrm{N}(0.05 \%)$, $\mathrm{S}(0.27 \%)$, and $\mathrm{Cl}(<0.01 \%)$. The wood dust had a low heating value of $3,370 \mathrm{kcal} \mathrm{kg}^{-1}$, and the metal content was non-detectable.

The RDF had $86.8 \%$ combustibles and low heating value of $5,800 \mathrm{kcal} \mathrm{kg}^{-1}$. The combustibles were mainly composed of C $(58.6 \%), \mathrm{O}(20.6 \%)$, and $\mathrm{H}(7.28 \%)$, with a trace of $\mathrm{N}$ (0.05\%), S (0.27\%), $\mathrm{Cl}(<0.01 \%), \mathrm{Cu}\left(490 \mathrm{mg} \mathrm{kg}^{-1}\right)$, and $\mathrm{Cr}$ $\left(262 \mathrm{mg} \mathrm{kg}^{-1}\right)$.

\section{Reclamation of RDF in Steam Generation Plant}

The remolded RDF was transported to a steam generation plant located in Northern Taiwan. The plant operating processes are shown in Fig. 2. Input materials, including RDF, coal, and wood dust were mixed in advance and fed into the combustion chamber via a chain-driven feeding unit. Table 2 shows the ingredients of the input materials in the four runs. To clarify the role of coal in the combustion process, the four runs were divided into Group I (without coal) and Group II (with coal). For Group I, 100\% wood dust and half-and-half RDF and wood dust served as the input materials in runs 1 and 2, respectively, to evaluate the combustion performance when RDF was substituted for the wood dust. In Group II, 50\% coal was used, and wood dust

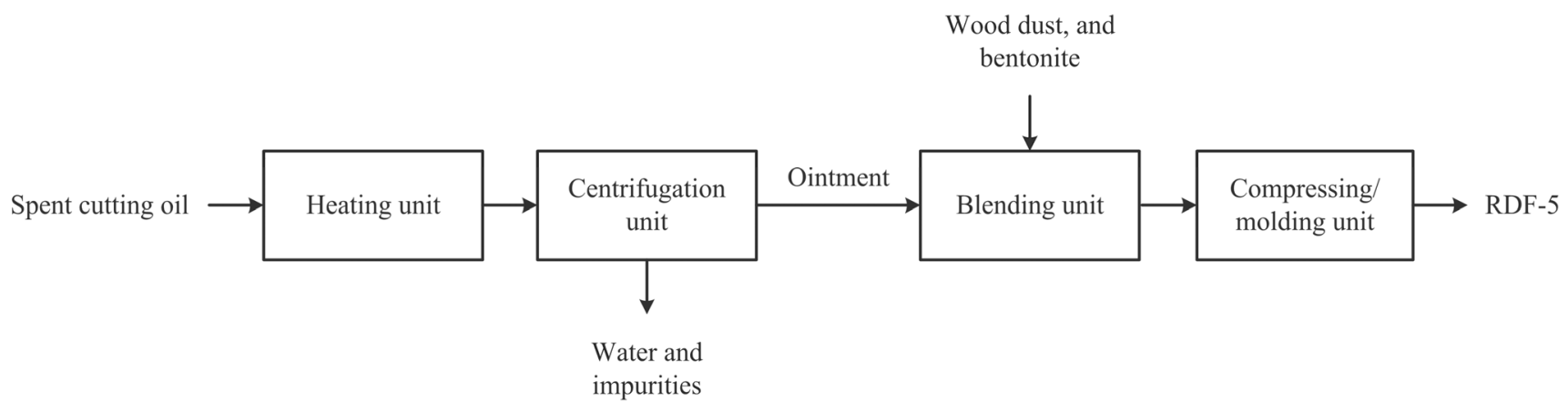

Fig. 1. RDF preparation process. 
Table 1. Properties of coal, wood dust, and RDF.

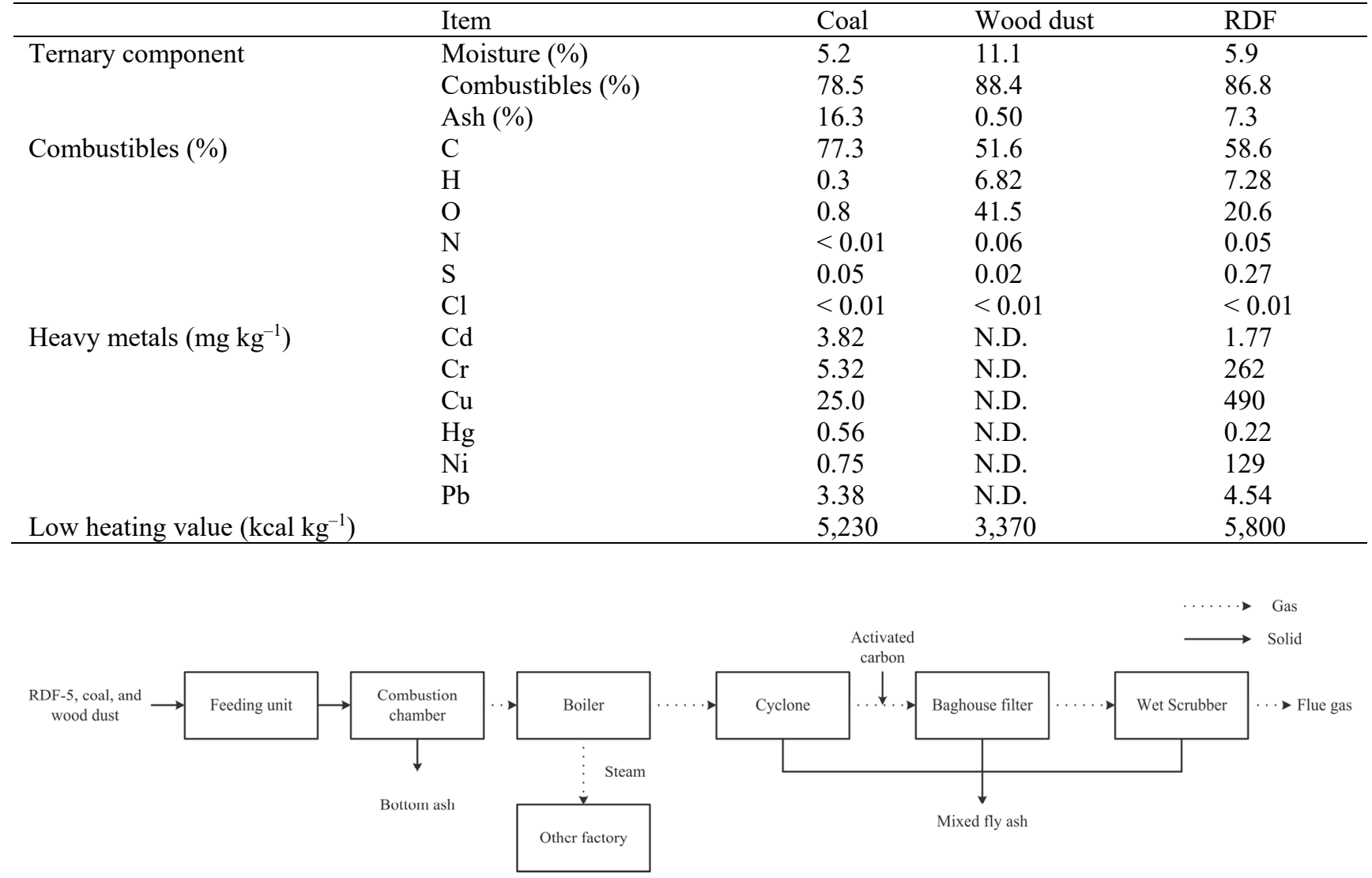

Fig. 2. RDF reclamation plant process flow diagram.

Table 2. The input materials in the RDF reclamation process.

\begin{tabular}{llllll}
\hline \multirow{2}{*}{ Input-materials } & \multicolumn{2}{c}{ Group I (without coal) } & & \multicolumn{2}{c}{ Group II (with coal) } \\
\cline { 2 - 3 } \cline { 5 - 6 } & Run-1 & Run-2 & & Run-3 & \multicolumn{1}{c}{ Run-4 } \\
\hline Coal & 0 & 0 & $50 \%$ & 0 & $50 \%$ \\
RDF & $0 \%$ & $50 \%$ & $50 \%$ & $50 \%$ & 0 \\
Wood dust & $100 \%$ & $50 \%$ & & $50 \%$ & 0 \\
\hline
\end{tabular}

and RDF accounted for the residual $50 \%$ in runs 3 and 4 , respectively, to evaluate the effect of a similar substitution of RDF in the case with coal.

The capacity of the input materials in the combustion chamber was 2 ton $\mathrm{hr}^{-1}$. The bottom ash was discharged into an ash pit and cooled using water. The flue gas emitted from the top of the combustion chamber passed through a boiler (LC-12, SZL) which generated steam sold to a nearby factory. The amount generated, the rated working pressure, and the rated steam temperature of the steam were 12 ton $\mathrm{hr}^{-1}, 10$ $16 \mathrm{~kg} \mathrm{~cm}^{-2}$, and $183-203^{\circ} \mathrm{C}$, respectively. The flue gas was cooled to approximately $300^{\circ} \mathrm{C}$ and was treated with a series of air pollution control devices, including a cyclone, a baghouse filter, and a wet scrubber. Coarse particulate $(>10 \mu \mathrm{m})$ was removed by the cyclone. After the cyclone removal, powdery activated carbon was injected to adsorb PCDD/Fs, and the particulates were filtered using the baghouse filter. Next, the wet scrubber was set to wash acid gas $\left(\mathrm{HCl}\right.$ and $\left.\mathrm{SO}_{2}\right)$ and then emitted to ambient air. The fly ashes emitted from the cyclone, semidry scrubber, and baghouse filter were collected together as mixed fly ash.

\section{Sampling of Flue Gas and Solid Specimens}

The stack flue gas was sampled at the point after APCDs (air pollution control devices) which was set up to remove air pollutants in the flue gas. Before the sampling of the PCDD/Fs, known amounts of surrogate standards pre-labeled with isotopes (including ${ }^{37} \mathrm{C}_{14}-2,3,7,8-\mathrm{TeCDD},{ }^{13} \mathrm{C}_{12}-1,2,3,4,7,8$ $\mathrm{HxCDD},{ }^{13} \mathrm{C}_{12}-2,3,4,7,8-\mathrm{PeCDF},{ }^{13} \mathrm{C}_{12}-1,2,3,4,7,8-\mathrm{HxCDF}$ and $\left.{ }^{13} \mathrm{C}_{12}-1,2,3,4,7,8,9-\mathrm{HpCDF}\right)$ were spiked to measure the collection efficiency of the sampling train. The sampling work followed the standard sampling procedure of PCDD/Fs in stack flue gas (TEPA, 2010) for which the detailed procedure was given in a previous study. The sampling and analysis of metals followed the standard method given in National Institute of Environmental Analysis A302.72C (TEPA, 2006). A flue gas sampler equipped with a cooling device, a holder with a fiberglass filter, a series of impingers, 
a pump, and a flow meter was used to sample flue gas isokinetically at an average flow rate of $5 \mathrm{~L} \mathrm{~min}^{-1}$. The detail sampling and analysis procedure of metals in flue gas were given in a previous study (Tsai et al., 2018; Chen et al., 2019).

A flue gas analyzer (E Instruments Combustion Analyzers, E6000) was used to continuously measure the gas concentrations of $\mathrm{O}_{2}, \mathrm{CO}_{2}, \mathrm{CO}, \mathrm{NO}_{\mathrm{x}}$, and $\mathrm{SO}_{\mathrm{x}}$ in the flue gas after the use of the APCDs. In addition, bottom ash and mixed fly ash were collected from the ash pits for further analysis.

\section{Analysis for PCDD/F, Metal Content, and Metal \\ Leaching Behavior}

The solid specimens were pretreated using a series of steps as follows: extraction with a mixed solvent (half-andhalf $n$-hexane and dichloromethane), determination of the nitrogen-blowing concentration, cleanup using silica gel, and nitrogen-blowing re-concentration for the $\mathrm{PCDD} / \mathrm{F}$ analysis. The solutions were then analyzed using a highresolution gas chromatograph (Hewlett-Packard 6970 Series gas, CA) and high-resolution mass spectrometer (Micromass Autospec Ultima, Manchester, UK) to identify seventeen $\mathrm{PCDD} / \mathrm{F}$ congeners. The procedure for the $\mathrm{PCDD} / \mathrm{F}$ analysis was conducted following a procedure given in a previous study (Han et al., 2017; Tsai et al., 2018).

To analyze the metal content, the solid specimens were all pulverized and digested using concentrated mixed acid following a digestion procedure, modified from the standard method provided in NIEA R317.10C (TEPA, 2002). The pulverized solid specimens $(\sim 0.1 \mathrm{~g})$ were added to a mixed acid composed of $3 \mathrm{~mL} \mathrm{HCl}(32 \mathrm{wt} \%)$ and $3 \mathrm{~mL} \mathrm{HNO}_{3}$ $(67 \mathrm{wt} \%)$. The mixture was held in sealed Teflon vessels and heated using a microwave digester (MARS Xpress, CEM). The specimens were all heated to $200^{\circ} \mathrm{C}$ at a rate of $6^{\circ} \mathrm{C} \mathrm{min}-1$, held isothermally for $20 \mathrm{~min}$, and cooled down to room temperature with forced ventilation. The digested solutions were diluted with deionized water to $50 \mathrm{~mL}$ and filtrated using mixed cellulose ester filters for further analysis.

The hazardous metal mobility of the bottom ash and mixed fly ash was evaluated using a toxicity characteristic leaching procedure (TCLP). An acid solution ( $\mathrm{pH}=4.93 \pm$ 0.05 ) was prepared as follows: $5.7 \mathrm{~mL}$ glacial acetic acid and $64.3 \mathrm{~mL} \mathrm{NaOH}$ solution $(1 \mathrm{~N})$ were added to $500 \mathrm{~mL}$ deionic water and were diluted using deionic water to $1000 \mathrm{~mL}$. The solid specimen and prepared solution were mixed with a mass ratio of solid:liquid $=1: 20$. The mixture was shaken overhead at $30 \pm 2$ turn $\mathrm{min}^{-1}$ for $18 \mathrm{hrs}$. The leachate was digested using concentrated $\mathrm{HNO}_{3}$ and filtered for further analysis. The detail procedure, including solution preparation, leaching conditions, dilution, digestion, and filtration, all followed the standard method stated in TEPA, 2003. The metal concentrations, including $\mathrm{Cd}, \mathrm{Cr}, \mathrm{Cu}, \mathrm{Hg}, \mathrm{Ni}$, and $\mathrm{Pb}$, in solution and digests were measured using atomic absorption spectroscopy (AAS, Agilent technologies 50AA).

\section{RESULTS AND DISCUSSION}

\section{Pollutants Characteristics of Flue Gas}

The concentrations of the air pollutants in the flue gas are shown in Table 3 and Fig. 2. In the case of the heavy metals, the concentrations in the flue gas in all four runs were much lower than those specified in the regulated standard. In Group I, the PCDD/F concentrations in the flue gas (19.6 and $21.9 \mathrm{ng}$ I-TEQ $\mathrm{Nm}^{-3}$ ) were obviously higher than those $\left(0.017\right.$ and $\left.0.226 \mathrm{ng} \mathrm{I-TEQ} \mathrm{Nm}^{-3}\right)$ in Group II. An extremely high concentration of $\mathrm{PCDD} / \mathrm{Fs}$ has been proven to be harmful to public health (Heiesh et al., 2018; Hung et al., 2018). Fig. 3 shows the PCDD/F patterns of the flue gas. The PCDD/F patterns of Figs. 3(a) and 3(b) were alike, and the $\mathrm{PCDD} / \mathrm{F}$ mass mainly distributed in $2,3,7,8-\mathrm{TeCDF}$, 1,2,3,7,8-PeCDF，2,3,4,7,8-PeCDF， 1,2,3,4,7,8-HxCDF, 1,2,3,6,7,8-HxCDF, 1,2,3,7,8,9-HxCDF, 2,3,4,6,7,8-HxCDF, and 1,2,3,4,6,7,8-HpCDF. As shown in Figs. 3(c) and 3(d), the patterns were somewhat similar, where the predominant $\mathrm{PCDD} / \mathrm{F}$ congeners were OCDF, OCDD, and 1,2,3,4,6,7,8 $\mathrm{HpCDF}$. The PCDD/F mass in the runs without coal was mainly distributed in 4-Cl to 6-Cl PCDD/Fs, while that in the runs with coal mainly existed as 7-Cl and $8-\mathrm{Cl} \mathrm{PCDD/Fs.}$

The continuous monitoring results and the regulated standard of the flue gas are shown in Fig. 4 and Table 4 (TEPA, 2018). Similar to the results for the PCDD/F patterns, the [CO] and $\left[\mathrm{O}_{2}\right]$ results in the same group were similar. In Fig. 4(a), many sharp peaks of [CO], probably resulting from partial smoldering, could be observed in the deep trough of $\left[\mathrm{O}_{2}\right]$ at the same time. Obviously, $\mathrm{CO}$ was largely generated during the condition of low $\left[\mathrm{O}_{2}\right]$. The replacement of $50 \%$ wood dust by RDF slightly reduced the averaged [CO] from 1240 to $886 \mathrm{ppm}$, and the averaged combustion efficiency (= $\left(\left[\mathrm{CO}_{2}\right] /\left(\left[\mathrm{CO}_{2}\right]+[\mathrm{CO}]\right) \times 100 \%\right)$ was improved from $96.98 \%$ to $97.59 \%$. In addition, the $\left[\mathrm{O}_{2}\right]$ slightly increased, and the fluctuations in $\left[\mathrm{O}_{2}\right]$ were also abated. For runs 3 and 4 , the coal addition improved the combustion efficiency to $>98 \%$, and the $\left[\mathrm{O}_{2}\right]$ went up to $>16 \%$. Thus, a great reduction of [CO] was observed in the two runs. This indicated that the

Table 3. Concentration of pollutants in the flue gas.

\begin{tabular}{|c|c|c|c|c|}
\hline \multirow{2}{*}{ Item } & \multicolumn{2}{|c|}{ Group I (without coal) } & \multicolumn{2}{|c|}{ Group II (with coal) } \\
\hline & Run-1 & Run-2 & Run-3 & Run-4 \\
\hline PCDD/Fs (ng I-TEQ $\mathrm{Nm}^{-3}$ ) & 19.6 & 21.9 & 0.226 & 0.017 \\
\hline $\mathrm{Cd}\left(\mathrm{mg} \mathrm{Nm}^{-3}\right)$ & 0.0172 & 0.0032 & 0.0264 & 0.0029 \\
\hline $\mathrm{Cr}\left(\mathrm{mg} \mathrm{Nm}^{-3}\right)$ & 0.0183 & 0.0143 & 0.0152 & 0.0153 \\
\hline $\mathrm{Cu}\left(\mathrm{mg} \mathrm{Nm}^{-3}\right)$ & 0.0546 & 0.0458 & 0.0347 & 0.0332 \\
\hline $\mathrm{Hg}\left(\mathrm{mg} \mathrm{Nm}^{-3}\right)$ & 0.0001 & 0.0017 & 0.0004 & $>0.0001$ \\
\hline $\mathrm{Ni}\left(\mathrm{mg} \mathrm{Nm}^{-3}\right)$ & 0.0079 & 0.0068 & 0.0057 & 0.0056 \\
\hline $\mathrm{Pb}\left(\mathrm{mg} \mathrm{Nm}^{-3}\right)$ & 0.331 & 0.0824 & 0.0261 & 0.0751 \\
\hline
\end{tabular}



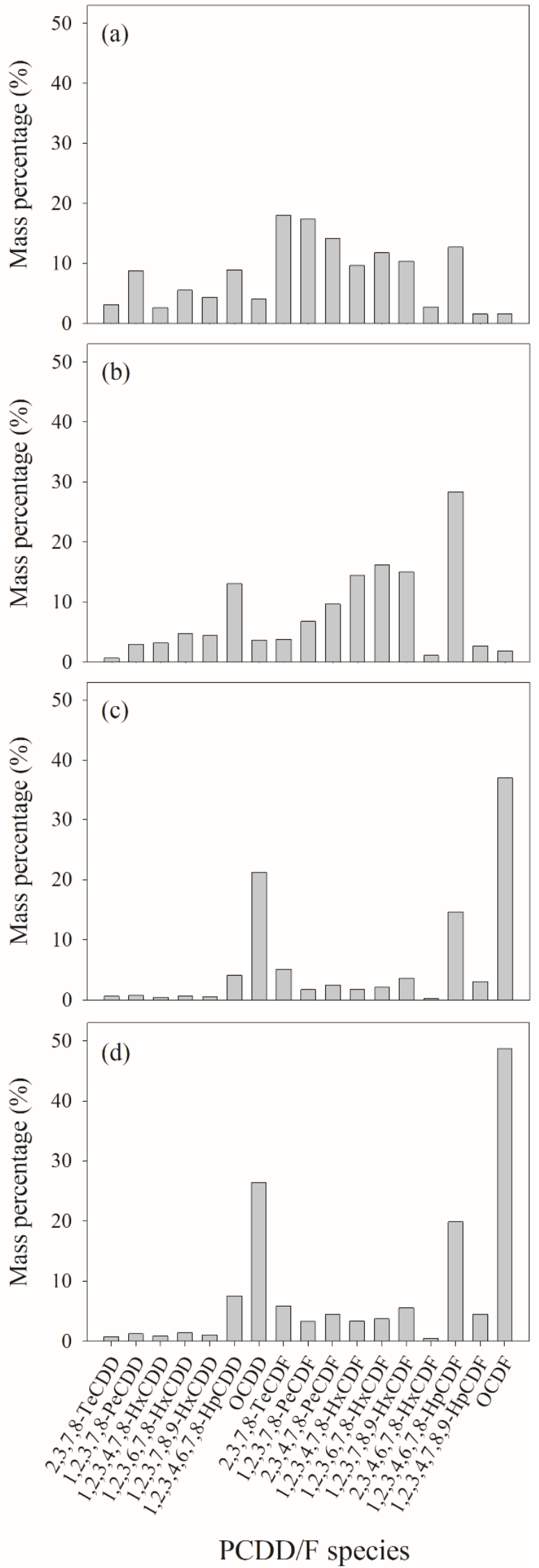

Fig. 3. PCDD/F profile of the flue gas in all runs: (a) Run-1; (b) Run-2; (c) Run-3; (d) Run-4.

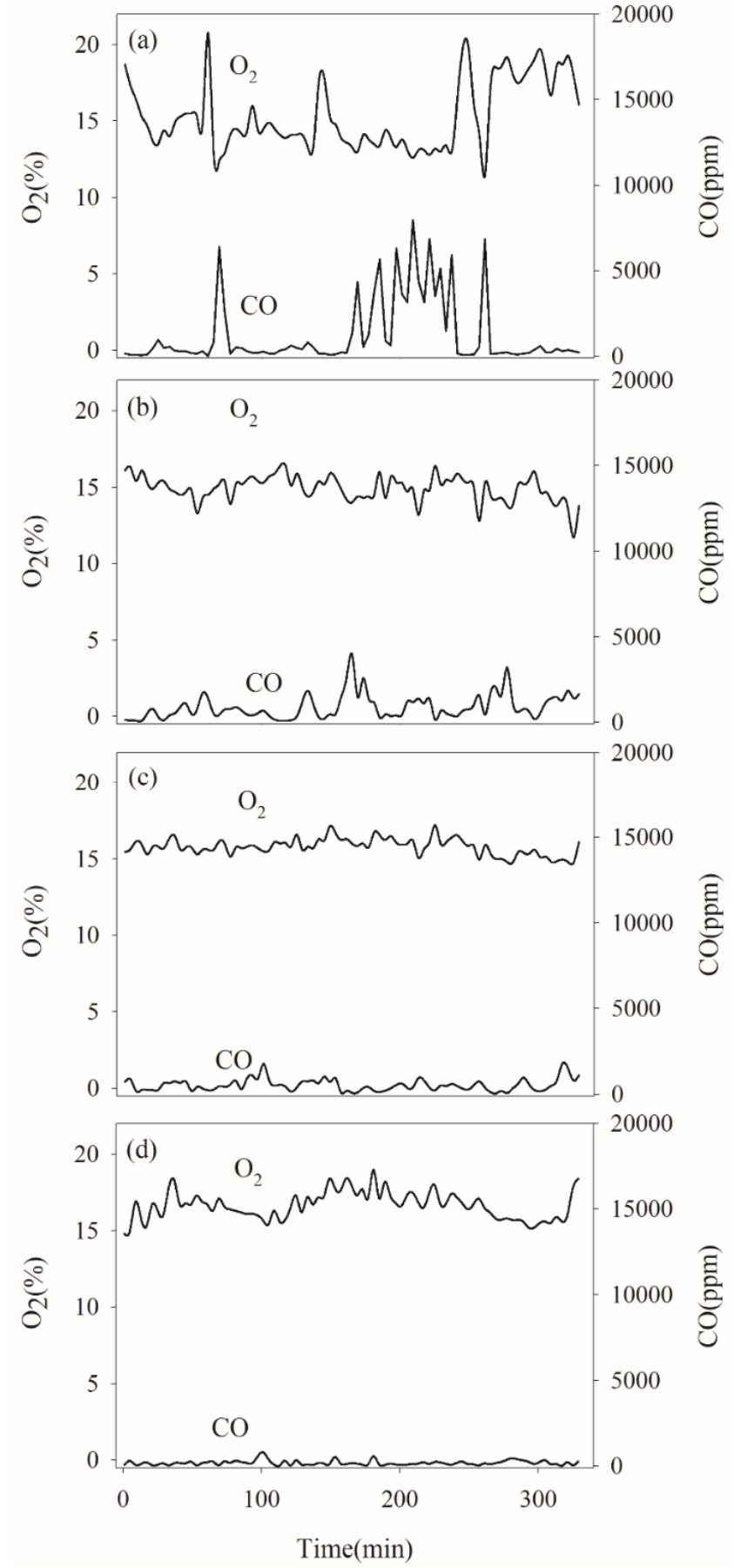

Fig. 4. Time sequence of $[\mathrm{CO}]$ and $\left[\mathrm{O}_{2}\right]$ : (a) Run-1; (b) Run2; (c) Run-3; (d) Run-4.

combustion with coal was more stable than that without coal, revealing that coal improves combustion conditions.

The substitution of RDF for wood dust further reduced the [CO] from $365 \mathrm{ppm}$ to $192 \mathrm{ppm}$ and improved the combustion efficiency from $98.65 \%$ to $99.18 \%$. Fig. 5 illustrates the $[\mathrm{CO}]$ versus $\left[\mathrm{O}_{2}\right]$ in the flue gas, which shows that the [CO] suddenly went up to an extremely high level while the $\mathrm{O}_{2}$ concentration went down to $>14 \%$. On the contrary, the [CO] was notably reduced when the $\left[\mathrm{O}_{2}\right]$ was higher than $16 \%$. 
Table 4. Concentration of pollutants in the flue gas.

\begin{tabular}{|c|c|c|c|c|c|c|c|c|c|}
\hline \multirow{3}{*}{ Item } & \multicolumn{4}{|c|}{ Group I (without coal) } & \multicolumn{4}{|c|}{ Group II (with coal) } & \multirow{3}{*}{$\begin{array}{l}\text { Regulated } \\
\text { standard }\end{array}$} \\
\hline & \multicolumn{2}{|c|}{ Run-1 } & \multicolumn{2}{|c|}{ Run-2 } & \multicolumn{2}{|c|}{ Run-3 } & \multicolumn{2}{|c|}{ Run-4 } & \\
\hline & Average & $\operatorname{RSD}(\%)$ & Average & $\operatorname{RSD}(\%)$ & Average & $\mathrm{RSD}(\%)$ & Average & $\mathrm{RSD}(\%)$ & \\
\hline $\mathrm{O}_{2}(\%)$ & 15.3 & 14.3 & 15.0 & 5.7 & 16.1 & 8.6 & 16.7 & 5.4 & -- \\
\hline $\mathrm{CO}_{2}(\%)$ & 3.16 & 38.6 & 3.35 & 3.34 & 4.17 & 3.65 & 2.37 & 21.32 & -- \\
\hline $\mathrm{CO}(\mathrm{ppm})$ & 1240 & 157 & 886 & 82.6 & 365 & 76.8 & 192 & 74.3 & -- \\
\hline $\mathrm{NO}_{\mathrm{x}}(\mathrm{ppm})$ & 90.2 & 15.9 & 60.5 & 78.1 & 117 & 38.5 & 42.0 & 25.4 & 100 \\
\hline $\mathrm{SO}_{\mathrm{x}}(\mathrm{ppm})$ & 45.0 & 109 & 7.0 & 14.3 & 22.0 & 35.1 & 6.7 & 81.5 & 50 \\
\hline $\begin{array}{l}\text { Combustion } \\
\text { efficiency }(\%)\end{array}$ & 96.98 & 3.8 & 97.59 & 1.76 & 98.65 & 0.54 & 99.18 & 0.65 & -- \\
\hline
\end{tabular}

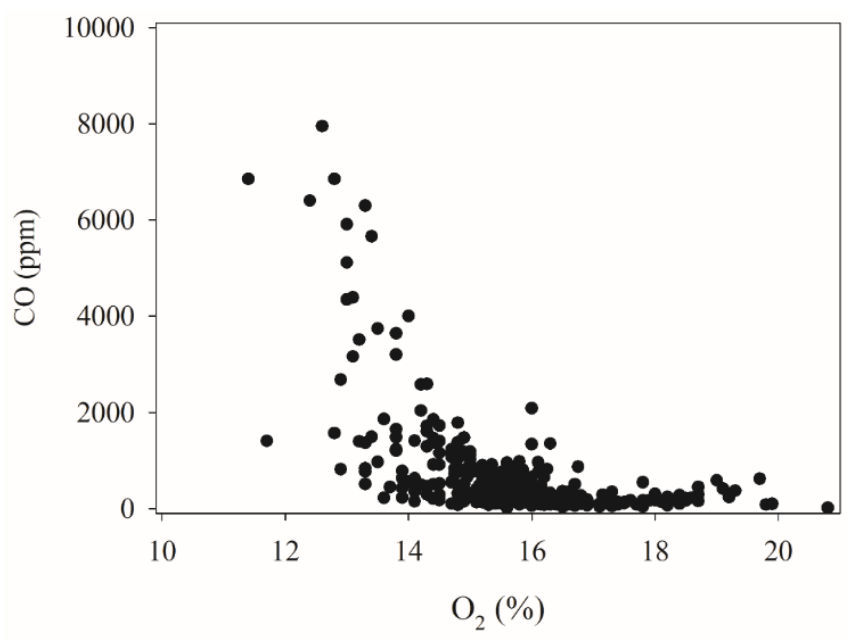

Fig. 5. $[\mathrm{CO}]$ vs. $\left[\mathrm{O}_{2}\right]$ in the flue gas.

\section{Pollutants Characteristics of Mixed Fly Ashes}

Table 5 shows the level of PCDD/Fs and heavy metals in all runs. Due to partial smoldering, the fly ashes in Group I had much higher levels of PCDD/Fs than those in Group II. The replacement of 50\% wood dust with RDF noticeably reduced the PCDD/F levels in the fly ash from 196 to $24.5 \mathrm{ng}$ $\mathrm{I}_{-}$TEQ $\mathrm{g}^{-1}$. However, the PCDD/F levels in the fly ash were still extremely high compared with those from the municipal solid waste incinerator due to poor combustion conditions (Wang et al., 2010). According to Fig. 4, the combustion in Group II was improved by coal, and thus the PCDD/F content in the fly ash was reduced to $4.95 \mathrm{ng}$ I-TEQ $\mathrm{g}^{-1}$ in run 3 . With the substitution of RDF for $50 \%$ wood dust, the PCDD/F content was further reduced to $0.03 \mathrm{ng}$ I-TEQ $\mathrm{g}^{-1}$. For the bottom ash, the PCDD/F level was much lower than that of the fly ash in the same run. The substitution of RDF for the wood dust also helped reduced PCDD/F levels from 0.348 to 0.007 and from 0.002 to $0.001 \mathrm{ng}^{\mathrm{I}-\mathrm{TEQ} \mathrm{g}^{-1}}$ in groups I and II, respectively.

The PCDD/F levels in the fly ash were two to four orders higher than those in the bottom ash. Therefore, the PCDD/F profiles of fly ash deserve investigation and are shown in Fig. 6. The PCDD/F profiles in Figs. 6(a) and 6(b) are similar and the similarity is consistent to the result of combustion condition (Figs. 4(a) and 4(b)). The consistence indicates that the RDF did not have significant effects leading to improvement in the combustion conditions in the case whitout coal as input materials.

Table 5. Content of pollutants in the fly ashes.

\begin{tabular}{|c|c|c|c|c|c|c|c|c|}
\hline \multirow{3}{*}{ Item } & \multicolumn{4}{|c|}{ Group I (without coal) } & \multicolumn{4}{|c|}{ Group II (with coal) } \\
\hline & \multicolumn{2}{|c|}{ Run-1 } & \multicolumn{2}{|c|}{ Run-2 } & \multicolumn{2}{|c|}{ Run-3 } & \multicolumn{2}{|c|}{ Run-4 } \\
\hline & FA & $\mathrm{BA}$ & FA & BA & FA & $\mathrm{BA}$ & FA & $\mathrm{BA}$ \\
\hline PCDD/Fs (ng I-TEQ g ${ }^{-1}$ ) & 196 & 0.348 & 24.5 & 0.007 & 4.95 & 0.017 & 0.03 & $<0.001$ \\
\hline $\mathrm{Cd}\left(\mathrm{mg} \mathrm{kg}^{-1}\right)$ & 180 & 4.88 & 294 & 1.22 & 0.52 & 0.03 & 0.74 & 0.31 \\
\hline $\mathrm{Cr}\left(\mathrm{mg} \mathrm{kg}^{-1}\right)$ & 113 & 156 & 104 & 870 & 130 & 250 & 118 & 201 \\
\hline $\mathrm{Cu}\left(\mathrm{mg} \mathrm{kg}^{-1}\right)$ & 747 & 2,960 & 874 & 970 & 440 & 750 & 293 & 536 \\
\hline $\mathrm{Hg}\left(\mathrm{mg} \mathrm{kg}^{-1}\right)$ & 6.83 & 1.14 & 2.3 & 0.28 & 0.335 & 0.158 & 0.267 & N.D. \\
\hline $\mathrm{Ni}\left(\mathrm{mg} \mathrm{kg}^{-1}\right)$ & 14.9 & 46.1 & 65.6 & 370 & 210 & 450 & 190 & 230 \\
\hline $\mathrm{Pb}\left(\mathrm{mg} \mathrm{kg}^{-1}\right)$ & 4,740 & 87.0 & 6,050 & 23.8 & 125 & 45.5 & 24.7 & 5.43 \\
\hline
\end{tabular}



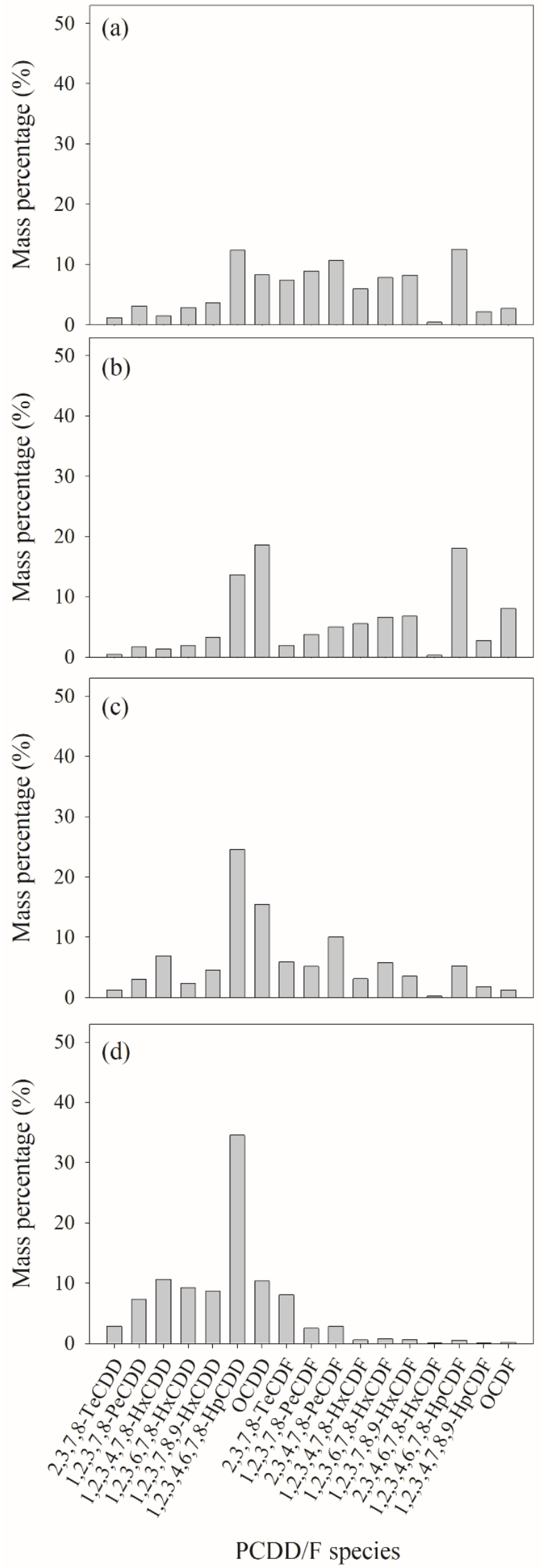

Fig. 6. PCDD/F profile of fly ashes in the runs with RDF: (a) Run-1; (b) Run-2; (c) Run-3; (d) Run-4.
For run 2, the fly ash and bottom ash had similar profiles. The predominant $\mathrm{PCDD} / \mathrm{F}$ congeners were OCDD, 1,2,3,4,6,7,8-HpCDF, and 1,2,3,4,6,7,8-HpCDD, for which their mass fractions were all roughly $20 \%$. For run 4 , $1,2,3,4,6,7,8-\mathrm{HpCDD}(34.6 \%)$ was the major $\mathrm{PCDD} / \mathrm{F}$ species in the fly ash, and 1,2,3,7,8-PeCDD, 1,2,3,4,7,8HxCDD, 1,2,3,6,7,8-HxCDD, 1,2,3,7,8,9-HxCDD, OCDD, $2,3,7,8-\mathrm{TeCDF}$ all accounted for approximately $10 \%$ of the $\mathrm{PCDD} / \mathrm{F}$ mass. In the bottom ash, the major $\mathrm{PCDD} / \mathrm{F}$ congener was OCDD (38.9\%), and the mass fractions of other congers, including 1,2,3,4,6,7,8-HpCDD, 2,3,7,8-TeCDF, 1,2,3,4,6,7,8$\mathrm{HpCDF}$, and OCDF, were all roughly $10 \%$.

In Group I, the fly ashes had much higher levels of $\mathrm{Pb}$ (4,740 $\mathrm{mg} \mathrm{kg}^{-1}$ in Run 1 and 6,050 mg kg-1 in Run 2). With the exception of these, the heavy metal levels in the ashes were all much lower than $5000 \mathrm{mg} \mathrm{kg}^{-1}$. The ashes in Group I had slightly higher levels of $\mathrm{Cu}$ than those in Group II, and $\mathrm{BA}$ had higher $\mathrm{Cu}$ levels than FA in the same run. The $\mathrm{Pb}$ and $\mathrm{Cu}$ might have come from the wood dust. Overall, heavy metals $(\mathrm{Cd}, \mathrm{Hg}$, and $\mathrm{Pb})$ with low boiling points mainly were present in the fly ash, while those with high boiling points $(\mathrm{Cr}, \mathrm{Cu}$, and $\mathrm{Ni})$ tended to stay in the bottom ash.

Table 6 shows the TCLP results for the ashes. For the fly ashes in Group II, the leaching concentration of the metals were all under the regulated standard. The $\mathrm{Cd}$ leaching concentration of fly ashes in Group I exceeded the regulated standard (TEPA, 2012). Therefore, the fly ash was declared to be a hazardous material and had to be solidified with cementation or vitrification before being transported to a landfill (Kuo et al., 2003). The bottom ashes were declared to be non-hazardous materials and could be directly recycled as building materials. Overall, the TCLP concentrations in the ash for the runs in Group I were slightly higher than those in Group II.

\section{CONCLUSIONS}

This study investigated the combustion performance of RDF, wood dust, and coal. For Group I, the PCDD/F concentrations of flue gas (19.6 ng I-TEQ $\mathrm{Nm}^{-3}$ in run-1 and $21.9 \mathrm{ng}$ I-TEQ $\mathrm{Nm}^{-3}$ in run-2) were two orders higher than those $(0.017 \mathrm{ng}$ I-TEQ $\mathrm{Nm}^{-3}$ in run-3 and $0.226 \mathrm{ng} \mathrm{I}^{-T E Q ~ N ~^{-3}}$ in run-4) for Group II, indicating that smoldering might occur under combustion conditions without coal. The substitution of RDF for wood dust by $50 \%$ slightly reduced the averaged $\mathrm{CO}$ concentration from 1240 to $886 \mathrm{ppm}$, and the averaged combustion efficiency was improved from $96.98 \%$ to $97.59 \%$. With coal, the combustion condition was more stable, and the combustion efficiency was improved to approximately $99 \%$. The results show that substitution of RDF for wood dust improved the combustion efficiency regardless of whether the combustion scenario included coal.

In the analysis of the $[\mathrm{CO}]$ versus $\left[\mathrm{O}_{2}\right]$ in the flue gas, the $[\mathrm{CO}]$ was greatly reduced while the $\left[\mathrm{O}_{2}\right]$ was higher than $16 \%$. Smoldering often occurred in the $\left[\mathrm{O}_{2}\right]<14 \%$ scenario, and $[\mathrm{CO}]$ peaks appeared. The TCLP results showed that bottom ash could be considered a non-hazardous material and could be directly recycled as a building material. Overall, the involved RDF was proven to be a suitable substitute for wood dust, especially in the combustion scenario with coal. 
Table 6. TCLP results for the ashes.

\begin{tabular}{|c|c|c|c|c|c|c|c|c|c|}
\hline \multirow{3}{*}{ Item } & \multicolumn{4}{|c|}{ Group I (with coal) } & \multicolumn{4}{|c|}{ Group II (without coal) } & \multirow{3}{*}{$\begin{array}{l}\text { Regulated } \\
\text { standard }\end{array}$} \\
\hline & \multicolumn{2}{|c|}{ Run-1 } & \multicolumn{2}{|c|}{ Run-2 } & \multicolumn{2}{|c|}{ Run-3 } & \multicolumn{2}{|c|}{ Run-4 } & \\
\hline & FA & BA & FA & BA & FA & BA & FA & $\mathrm{BA}$ & \\
\hline $\mathrm{Cd}\left(\mathrm{mg} \mathrm{L}^{-1}\right)$ & 1.43 & 0.09 & 2.21 & 0.01 & 0.35 & 0.01 & N.D. & N.D. & 1.0 \\
\hline $\mathrm{Cr}\left(\mathrm{mg} \mathrm{L}^{-1}\right)$ & 0.62 & 0.40 & 0.44 & 0.13 & 0.36 & 0.15 & 0.011 & $<0.010$ & 5.0 \\
\hline $\mathrm{Cu}\left(\mathrm{mg} \mathrm{L}^{-1}\right)$ & 0.14 & 1.31 & 0.07 & 0.49 & 0.05 & 0.33 & N.D. & N.D. & 15 \\
\hline $\mathrm{Hg}\left(\mathrm{mg} \mathrm{L}^{-1}\right)$ & N.D. & N.D. & N.D. & N.D. & N.D. & N.D. & N.D. & N.D. & 0.2 \\
\hline $\mathrm{Pb}\left(\mathrm{mg} \mathrm{L}^{-1}\right)$ & 0.4 & 0.15 & 0.21 & 0.11 & 0.2 & 0.17 & N.D. & N.D. & 5.0 \\
\hline
\end{tabular}

\section{REFERENCES}

Arena, U. (2012). Process and technological aspects of municipal solid waste gasification. A review. Waste Manage. 32: 625-639.

Arena, U., Mastellone, M.L. and Perugini, F. (2003). The environmental performance of alternative solid waste management options. Chem. Eng. J. 96: 207-222.

Azapagic, A., Perdan, S. and Clift, R. (2004). Sustainable development in practice. J. Wiley \& Sons. Ltd., Chicester, UK.

Bucher, R., Diederich, P., Escadeillas, G. and Cyr, M. (2017). Service life of metakaolin-based concrete exposed to carbonation Comparison with blended cement containing fly ash, blast furnace slag and limestone filler. Cem. Concr. Res. 99: 18-29.

Chang, N.B., Wang, H.P., Huang, W.L. and Lin, K.S. (1999). The assessment of reuse potential for municipal solid waste and refuse-derived fuel incineration ashes. Resour. Conserv. Recycl. 25: 255-270.

Chen, S., Cui, K., Zhao, Y., Yin, Z., Chao, H.R. and ChangChien, G.P. (2018). Sensitivity analysis of atmospheric $\mathrm{PM}_{2.5}$-bound content and dry deposition of total PCDD/Fs-TEQ: In the case of Xiamen and Zhangzhou, China. Aerosol Air Qual. Res. 18: 3096-3114.

Consonni, S., Giugliano, M. and Grosso, M. (2005). Alternative strategies for energy recovery from municipal solid waste. Part A: Mass and energy balances. Waste Manage. 25: 123-135.

Directive 2008/98/EC of the European Parliament and of the Council on Waste and Repealing Certain Directives Annex II, 19 November 2008.

Gug, J., Cacciola, D. and Sobkowicz, M.J. (2015). Processing and properties of a solid energy fuel from municipal solid waste (MSW) and recycled plastics. Waste Manage. 35: 283-292.

Han, Y., Liu, W., Li, H., Lei, R., Gao, L., Su, G. and Liu, G. (2017). Gas-particle partitioning of polychlorinated dibenzo- $p$-dioxins, dibenzofurans, and biphenyls in flue gases from municipal solid waste incinerators. Aerosol Air Qual. Res. 17: 2847-2857.

Hsieh, Y.K., Chen, W.S., Zhu, J., Wu, Y.J. and Huang, Q. (2018). Health risk assessment and correlation analysis on PCDD/Fs in the fly ash from a municipal solid waste incineration plant. Aerosol Air Qual. Res. 18: 734-748.

Hung, N.T., Ting, H.W. and Chi, K.H. (2018). Evaluation of the relative health risk impact of atmospheric PCDD/Fs in $\mathrm{PM}_{2.5}$ in Taiwan. Aerosol Air Qual. Res. 18: 2591-2599.
Kuo, Y.M., Lin, T.C. and Tsai, P.J. (2003). Effect of $\mathrm{SiO}_{2}$ on immobilization of metals and encapsulation of a glass network in slag. J. Air Waste Manage. Assoc. 53:14121416.

Leme, M.M.V., Rocha, M.H., Lora, E.E.S., Venturini, O.J., Lopes, B.M. and Ferreira, C.H. (2014). Techno-economic analysis and environmental impact assessment ofenergy recovery from Municipal Solid Waste (MSW) in Brazil. Resour. Conserv. Recycl. 87: 8-20.

Lombardi, L., Carnevale, E. and Corti, A. (2015). A review of technologies and performances of thermal treatment systems for energy recovery from waste. Waste Manage. 37: $26-44$.

Murer, M.J., Spliethoff, H., De Waal, C.M.W., Wilpshaar, S., Berkhout, B., Van Berlo, M.A.J, Gohlke, O. and Martin, J.J.E. (2011). High efficient waste-to-energy in Amsterdam: Getting ready for the next steps. Waste Manage. Res. 29: 20-29.

Myrin, E.S., Persson, P.E. and Jansson, S. (2014). The influence of food waste on dioxin formation during incineration of refuse-derived fuels. Fuel 132: 165-169.

Nam-Chol, O. and Kim, W.G. (2017). Investigation of characterization of municipal solid waste for refusedderived fuel, a case study. Energy Sources Part A 39: 1671-1678.

Nasrullah, M., Vainikka, P., Hannula, J., Hurme, M. and Kärki, J. (2015). Mass, energy and material balances of SRF production process. Part 3: Solid recovered fuel produced from municipal solid waste. Waste Manage. Res. 33: 146-156.

Psomopoulos, C.S., Bourka, A. and Themelis, N.J. (2009). Waste-to-energy: A review of the status and benefits in USA. Waste Manage. 29: 1718-1724.

Rada, E.C. and Andreottola, G. (2012). RDF/SRF: Which perspective for its future in the EU. Waste Manage. 32: 1059-1060.

TEPA (Taiwan Environmental Protection Administration) (2002). Standard Method for Analyzing Heavy Metals in Extracts from Industrial Waste Acid Digestion with Microwave. NIEA R317.10C.

TEPA (Taiwan Environmental Protection Administration) (2003). Toxicity Characteristic Leaching Procedure. NIEA R201.14C.

TEPA (Taiwan Environmental Protection Administration) (2006): Standard Method of Detection of Heavy Metals in Outlet Line; NIEA A302.72C; Taiwan Environmental Protection Administration: Taiwan.

TEPA (Taiwan Environmental Protection Administration) 
(2010). Standard Sampling Method for PCDD/Fs of Flue Gas; NIEA A807.75C.

TEPA (Taiwan Environmental Protection Administration) (2012). Waste Disposal Act, 2009. The Standard of Hazardous Industrial Wastes Identification; EPA://07e0020; Waste/Waste Disposal: 0950098457.

TEPA (Taiwan Environmental Protection Administration) (2018). Pollutants Emission Regulated Standards for Small and Medium Boiler: Atmospheric Pollution/ Air Pollution; 1070074601.

Tsai, J.H., Chen, S.J., Li, P.M., Chang-Chien, G.P., Huang, K.L., Tsai, C.H., Hsieh, C.Y. and Lin, C.C. (2018). Characteristics of $\mathrm{PM}_{2.5}$-bound $\mathrm{PCDD} / \mathrm{Fs}$, PCBs, $\mathrm{PBDD} / \mathrm{Fs}$ and PBDEs from a diesel generator using waste cooking oil-based biodiesel blends. Aerosol Air Qual. Res. 18: 2583-2590.

Vermeulen, I., Caneghem, V.J., Block, C., Baeyens, J. and Vandecasteel, C. (2011). Automotive shredder residue
(ASR): Reviewing its production from end-of-life vehicles (ELVs) and its recycling, energy or chemicals' valorization. J. Hazard. Mater. 190: 8-27.

Wang, L.C., His, H.C., Wang, Y.F., Lin, S.L. and ChangChien, G.P. (2010). Distribution of polybrominated diphenyl ethers (PBDEs) and polybrominated dibenzo- $p$-dioxins and dibenzofurans (PBDD/Fs) in municipal solid waste incinerators. Environ. Pollut. 158: 1595-1602.

Zhou, C., Zhang, Q., Arnold, L., Yang, W. and Blasiak, W. (2013). A study of the pyrolysis behaviors of pelletized recovered municipal solid waste fuels. Appl. Energy 107: 173-182.

Received for review, September 30, 2019

Revised, October 24, 2019

Accepted, October 24, 2019 